\title{
The Implementation of Cascading in the Regional Governments
}

\author{
Idel Eprianto $^{1}$, Shafrani Dizar ${ }^{2 *}$ \\ \{shafrani@trisakti.ac.id\} \\ Faculty of Economics and Business, Bengkulu University, Bengkulu, Indonesia \\ Faculty of Economics and Business, Trisakti University, Jakarta, Indonesia
}

\begin{abstract}
The regional governments make organizational decisions that must be in line with goal setting. The government management system is expected to focus on increasing accountabilitywhile improving results-oriented performance (outcome) at the same time. Cascading is a process of decreasing and aligning organizational targets to work units at all levels in the organization in a hierarchical manner. This process can be carried out to the lowest level, namely to the individual level. Therefore, there is an alignment of roles at all levels of the organizational unit. Cascading carried out in the regional government greatly affects the performance of the regional government in the Government Agency Performance Accountability System (Indonesian: Sistem Akuntabilitas Kinerja Instansi Pemerintah (SAKIP)). The purpose of this study was to find out the implementation of cascading in the regional governments of Kerinci Regency, Jambi Province and Rejang Lebong Regency, Bengkulu Province, in realizing a clean, accountable, and high-performing government. In this study, researchers applied a qualitative approach with a descriptive analysis method. The results showed that, in general, cascading has been carried out to improve the quality of governance in Kerinci Regency, Jambi Province and Rejang Lebong Regency, Bengkulu Province. However, the implementation of cascading in achieving the Key Performance Indicators (KPIs) for Regional Heads still needs to be revised or improved so that all Regional Apparatus Organizations (Indonesian: Organisasi Perangkat Daerah (OPD)) can align the KPIs for Regional Heads with the KPIs for Regional Apparatus Organizations to attain the vision and mission of the regional government.
\end{abstract}

Keywords: Cascading; Performance Planning; Key Performance Indicators; Performance Report

\section{Introduction}

The improvement of governance and management systems is an important agenda in bureaucratic reform that is currently being carried out by the government. The government management system is expected to focus on increasing accountability while improving resultsoriented performance (outcome) at the same time. Therefore, the government must establish policies for the implementation of a clear, regular, and effective accountability system. The 
concept of new public management has also changed the paradigm of government management towards a flexible and professional government system. However, government performance indicators have not shown the suitability of information (logical relationship) between planning documents and reporting documents [1].

The Key Performance Indicators (KPIs) must be used as a reference for all organizational units in preparing, implementing, monitoring, controlling, and reporting annual performance plans [2]. The Key Performance Indicators (KPIs) are measures or indicators that can provide information on to what extent the success in realizing the strategic goals that have been set [3]. Government agencies as public service institutions are obliged to compile the KPIs as a measure or benchmark for the success of organizational performance. Furthermore, to measure the level of success of an organization, clear indicators are highly needed by stakeholders. Performance indicators are quantitative and qualitative measures that describe the level of achievement of a predetermined target or goal [4]. Therefore, performance indicators must be calculated, measured, and used as a basis forassessing or seeing the level of performance in the planning stage, implementation stage, and after-activity stage. In other words, without performance indicators, it is difficult to assess the level of success or failure of an organization's policies or programs. With performance indicators, an organization may have a clear instrument of how a policy or program is considered to be successful or unsuccessful in the future.

Indonesia's Presidential Regulation No. 29/2014 explains that the Government Agency Performance Accountability System (Indonesian: Sistem Akuntabilitas Kinerja Instansi Pemerintah (SAKIP)) It is a systematic set of different activities, tools, and processes designed for the purpose of identifying and measuring, collecting data, classifying, summarizing, and reporting on government accountability and improving government performance.. Furthermore, Indonesia's Minister of Empowerment of State Apparatus and Bureaucratic Reform Regulation No. 12/2015 also explains in detail the Guidelines for Evaluation of the Implementation of SAKIP. These guidelines are used as a reference for evaluating the implementation of SAKIP within government agencies and/or Regional Work Units (Indonesian: Satuan Kerja PerangkatDaerah (SKPD)). Furthermore, these guidelines are an integral part of the ministerial regulation. The technical policy for evaluating the implementation of SAKIP includes the focusof the evaluation, the timing of the evaluation, the assignment of evaluations, and others deemed necessary. Every head of government agency evaluates the implementation of SAKIPin their government annually. The evaluation is carried out by their respective internalsupervisory officers and the results of the evaluation are used to improve performancemanagement and performance accountability, especially the performance of public services intheir respective agencies on an ongoing basis [5]. The 2019 Government Work Plan (Indonesian: Rencana Kerja Pemerintah (RKP)) is regulated through Indonesia's

Presidential Regulation No. 72/2018 concerning the implementation guidelines for central and regional governments to achieve state goals as stated in the Preamble to the 1945 Constitution. The 2019 Government Work Plan is the direction of the national development policy for one year. This policy direction is a form of the government's commitment to providing certainty in policy, funding, regulatory framework, public services, and investment for the sustainability ofthe implementation of national development.

In the era of regional autonomy, regional heads are elements of regional government administrators who have Responsibility for the achievement of the mission and objectives of the implementation of regional autonomy. In realizing the purpose of the establishment of regional autonomy, regional leaders are needed as top managers who are professional and effective in managing regional government organizations. Regional heads often experience 
problems in realizing their political promises during their term of office. Therefore, the regional government planning must describe results that have a direct impact on the community because the presence of the state is represented by regional governments reflected in their activity programs that are in line with development goals.

The results of the observation carried out by researchers show that most of theperformance indicators of work units in this regional government have not shown results-basedperformance indicators so that they have not fully supported the government's performance. In creating a performance measurement system, the governments of Kerinci Regency, Jambi Province and Rejang Lebong Regency, Bengkulu Province must consider input indicators, output indicators, outcome indicators, benefit indicators, and impact indicators because performance indicators are made to make it easier to assess the level of success and failure of work programs in the context of continuous quality improvement. Therefore, the selected development targets have measurable performance measures and clear targets. This is needed to make it easier to determine the success or failure of the development targets. Furthermore, to make it easier to choose the most appropriate program strategy, cascading can be carried outbased on the goal achievement process. Cascading is the elaboration of performance and key performance indicators into more detailed performance or the conditions that affect it using a logical framework. Cascading is used to formulate what performance should at the lower level or formulate what activities must be carried out.

In performance planning, there must be a process of decreasing and aligning orcascading performance down to the organizational unit at the lowest level so that all programs and activities to be implemented have relevance and causality to efforts in achieving the visionand mission of the organization.Cascading is one of the indicators to assess government performance as outlined in SAKIP. Because the performance of the regional governments has not been optimal yet, they must perform cascading to align and divide tasks in detail and correctly down to the lowest level so that synchronization between the government may occur at central, provincial, and regional levels. Furthermore, every program carried out by OPD can support the vision and mission of the regional head. If cascading is carried out in line with technical guidelines basedon rules and legislation, then the vision and mission of the regional head can be implemented properly by OPD concerned and synchronization between the central and regional governmentscan be realized.

\section{Objective}

The specific objective of this study was to determine the extent of the success of the regional governments in implementing cascading to achieve the Regional Government Performance Accountability in Kerinci and Rejang Lebong Regencies.

\section{Literature Review}

\subsection{Performance Planning}

Performance planning is the process of preparing a performance plan as an elaboration of the targets and programs that have been set in the strategic plan, which will be carried out by government agencies through various annual activities. The National Development Planning System is a unified development planning procedure to produce long-term, medium-term, and annual development plans implemented by elements of state administrators and the society at 
the central and regional levels. Development planning consists of four stages, namely plan preparation, plan determination, plan implementation control, and plan implementation evaluation.

A Work and Budget Plan (Indonesian: Rencana Kerja dan Anggaran (RKA)) is a planning and budgeting document that contains income plans, expenditure plans \& activity plans of Regional Work Units (Indonesian: Satuan Kerja Perangkat Daerah (SKPD)), and financing plans. The process of preparing RKA is the first step in implementing the work program that has been set previously. The calculation in this process can be used as a benchmark for whether the implementation of the work program can be carried out properly in the coming year. Because the reparation of RKA SKPD must be based on the memorandum ofagreement in General Budget Policy and Budget Priority (Indonesian: Kebijakan Umum Anggaran (KUA) and Prioritas Plafon Anggaran (PPA)), the Regional Government Budget Team (Indonesian: Tim Anggaran Pemerintah Daerah (TAPD)) must refer to Indonesia's Minister of Home Affairs Regulation No. 86/2017.

\subsection{Key Performance Indicators (KPIs)}

Key Performance Indicators (KPIs) are performance measures or indicators of an agency, which are primarily used in achieving certain goals and objectives. Every governmentagency is obliged to formulate key performance indicators and make them a top priority. By formulating key performance indicators, government agencies can find out to what extent of their performance. At the same time, Key Performance Indicators can also improve the performance of government agencies. Therefore, those government agencies can achieve the goals, objectives, and plans that have been determined previously. These indicators are useful for setting performance targets for assessing progress towards targets. Furthermore, it is to compare the performance of different work units, organizations, ministries, or institutions [6].

In its preparation, the KPIs must meet certain criteria, especially from SKPD. Those criteria are as follows.

1. Specific. Key performance indicators should be as specific as possible and also relate to what the indicator measures (in this case, the performance of employees and partner agencies). This is done so that the people who create the KPIs have the same perception of the KPIs that they set.

2. Measurable. KPIs must be able to be measured objectively, either through a quantitative or qualitative approach.

3. Available. Responsible bodies should be able to collect the data used in the KPIs.

4. Relevant. KPIs must accurately describe an agency's performance and be relevant to the agency's real-world conditions

5. Timelines. KPIs that have been compiled must be able to describe data in the form of performance developments of an institution within a certain period of time. In addition, KPIs must be able to be as flexible as possible if there are certain changes in them later.

\subsection{Cascading}

Performance cascading is the process of elaborating and aligning strategic goals, key performance indicators, and targets of the KPIs vertically from a higher unit/employee level toa lower unit/employee level. Cascading can be carried out in two methods, namely direct and indirect methods (Kaplan \& Norton, 2014). 
1) Direct method

This can be carried out by directly making the strategic targets, KPIs, and strategic initiatives from the higher units as strategic targets, KPIs, and strategic initiatives of the unit. Therefore, strategic targets, KPIs, and strategic initiatives from those units are thesame.

2) Indirect method

The preparation of strategic targets, KPIs, and strategic initiatives in a unit is carried out by developing strategic targets, KPIs, and strategic initiatives at a higher organizational level, referring to the duties and functions of the unit concerned. Meanwhile, all KPI achievement targets at higher organizational levels are lowered to units below them in accordance with the burdens and objectives of each unit.

In relation to performance, the cascade is applied as a process of decreasing and aligning organizational targets to work units at all levels in the organization in a hierarchical manner. This process can be carried out to the lowest level, namely up to the individual level so that the alignment of roles at all levels of the organizational unit may occur. This alignment is carried out on all components of the strategic plan starting from the vision to the implementation of work activities.

\subsection{Performance Report}

Government agencies consistently follow the performance measurement system formulated by the Financial and Development Supervisory Agency (Indonesian: Badan Pengawas Keuangan dan Pembangunan (BPKP)). However, in the performance measurement system adopted, efficiency is not a performance measure that must be developed [7]. Performance measurement systems in public sector organizations should be based on the goals set by the strategic plan and should measure the achievements [8]. In addition to this, the clarity of budget targets has an effect on the government agency's accountability for performance [9]. An organization must be "accountable" in setting appropriate goals, developing standards needed to achieve the goals set, effectively promoting the adoption of standards, and developing organizational \& operating standards economically and efficiently (Herbert \& Killoughmanajemen, 2007). Accountability indicators in the measurement model for the implementation of good governance are (a) budget management accountability, (b) performance accountability, (c) deviation intensity, and (d) deviation follow-up (Jubaedah, 2008:66). Apart from that, the implementation of accountability requires transparency (Shende \& Bennett, 2004).

Indonesia's Presidential Regulation No. 29/2014 explains in detail the Accountability of the Performance of Government Agencies. The Government Agency Performance Accountability System (Indonesian: Sistem Akuntabilitas Kinerja Instansi Pemerintah (SAKIP)) is a systematic series of various activities, tools, and procedures designed for the purposes of determining \& measuring, collecting data, classifying, summarizing, and reporting performance at the government agency, in the context of accountability and performance improvement of government agencies. Furthermore, Indonesia's Minister of Empowerment of State Apparatus and Bureaucratic Reform Regulation No. 12/2015 also explains in detail the Guidelines for Evaluation of the Implementation of SAKIP. These guidelines are used as a reference for evaluating the implementation of SAKIP within government agencies and/or Regional Work Units (Indonesian: Satuan Kerja Perangkat Daerah (SKPD)). 


\subsection{Supporting TheoriesGoal Setting Theory}

The goal-setting referred to in this study is concerning management. According to Robbins \& Coulter (2012), management is defined as a work activity that involves coordinating supervision of work so that the work can be completed efficiently and effectively [10]. The goal- setting theory implies that an individual is committed to a goal [11]. If an individualhas a commitment to achieve his goals, then that commitment will affect his actions and the consequences of his performance.

Goal setting theory emphasizes the importance of the relationship between set goals and resulting performance. Its basic concept is that if someone is able to understand the expected goals of an organization, that understanding will affect their performance. This theory assumes that for optimal performance there must be a congruence of goals within the organization. Therefore, according to this theory, the good performance of employees in the provision of public services is identified as a goal. With goal setting, people can see the results of their current job and compare it to the results of their previous job. This can create a separate motivation for people to try even harder to achieve their goals. Locke (in Kusuma, 2013) found that goal setting has an impact on budget accuracy. Every organization should establish goals that are formulated in a budget plan to facilitate the achievement of performance goals in line with the vision and mission of the organization. A budget plan not only contains plans and the nominal costs necessary to carry out activities / programs, it must also contain the goals that the organization intends to achieve.

Achievement of stated goals can be viewed as individual goals to be achieved / performance levels. People need to have skills, objectives, and feedback to evaluate their performance. The achievement of goals has an impact on the behavior and performance of employees within the organization [12]. Like Locke, Robbins (2008) found that goal setting can affect budget accuracy. Every organization should establish goals that are formulated in a budget plan to facilitate the achievement of performance goals in line with the vision and mission of the organization [11].

\subsection{Agency Theory}

According to Jensen \& Meckling (1976), an agency relationship is a contractbetween the principal and the agents, by considering the delegation of some decision-making authority to the agent [13]. As agents, the managers have a moral responsibility to maximize the profits of the owners (principal). On the other hand, they also have an interest in maximizing personal welfare. The agency theory can also be applied to the public sector. A democratic country has an agency relationship between the community and the government or between the regional government and the central government. The central government gives authority to regional governments. Therefore, regional governments must also be responsible for their duties to the central government. On the other hand, regional governments must also maximizetheir welfare.

According to the agency theory, the management of the regional governments must be monitored to ensure that the management is carried out in full compliance with various applicable regulations and provisions. With the increased accountability of regional governments, the information received by the public becomes more balanced against regionalgovernments, meaning that the information asymmetry that occurs can be reduced. Furthermore, with the reduced information asymmetry, the possibility of corruption is also getting smaller. 
The government must be able to become the subject of information providers to fulfillthe rights of the public, namely the right to be informed, the right to have their aspirations heard, and the right to be given an explanation. In the context of the agency theory, the provision of information is intended to minimize agent costs due to information asymmetry. One of the information that is quite vital (besides financial reports) that must be provided is information on the performance of regional governments because, from this kind of information, the principal will know the level of success or failure of a government agency which is measured by to what extent of the actual performance of the activity (program) if being compared to the plan and to what extent of the benefits of the performance of activities (program) to the public. Jones \& Pendlebury (2000) state that the measurement of public sectorperformance is carried out to fulfill three purposes, namely (1) helping improve government performance, (2) making resource allocation and decision-making to be effective, and (3) realizing public accountability and improving institutional communication.

\subsection{Related Previous Studies}

Attributes that become weaknesses in the implementation of the performance accountability system of the government of Bogor City are alignment between planning documents, results-oriented performance planning, linkage of programs/activities with strategic plans, preparation of individual performance indicators, tiered performance measurement, and utilization of performance measurement [14]. In performance planning, there must be a process of decreasing and aligning or cascading performance down to the organizational unit at the lowest level so that all programs and activities to be implemented have relevance and causality to efforts in achieving the vision andmission of the organization [15]. The strategic plan is presented in a strategy map that is handed down to the work units of the Directorate of Medical and NursingServices, the Directorate of Human Resources Support and Development, and the Directorate of General Administration by using cascading techniques to increase the effectiveness of performance achievement at all levels of management [16]. To achieve an accountable performance, the government planning system must at least meet the results- oriented criteria and have alignment in it. This means that the activities carried out must have causality and alignment to achieve the final goals that have been set. Every activity that is carried out logically will always impact the activities above it, meaning that all activities havea contribution to the achievement of the final goal [17].

The cascading framework can be used to find the optimal solution to the problem at hand. The purpose of the cascading framework is to optimize the process and formulation of a strategy that uses a sequence of functions to approximate the real value [18]. Cascading can no longer be considered as a marginal topic but needs to be applied better in formulating plans, including considerations about its relationship with developing policies and practices. Cascading can be applied to several key strategic actions, such as Integrating risk maps, clarifying the attribution of responsibilities, building and planning contingencies, and supporting awareness of interdependence with decision-makers [19]. The clarity of budget targets has an impact on the performance accountability of government agencies [9]. Performance measurement is also facilitated by management changes resulting from theprocess of merging and aligning programs [20].

Performance measurement systems in public sector organizations should be based on the goals set by the strategic plan and shouldmeasure the achievements [8]. The clarity of budget targets has a positive effect on the performance accountability of government agencies. This indicates that the clarity of targets will help employees to achieve the expected performance. 
In other words, the clearer the budget targets are, the easier it will be for employees to account for the success or failure of task execution periodically [21]. Limitations and uncertainties over the amount and quality of responsibility for the budget management in the Education Offices in Bengkulu Province have created conditions that are contrary to the conditions that they should be [22]. Absorption of budgets that are not in line with planning is one of the obstacles in the management of regional finances. Furthermore, the weak coordination between offices is also a factor that causes the low quality of the Government Agency Performance Accountability Report (Indonesian: Laporan Akuntabilitas Kinerja Instansi Pemerintah (LAKIP)) [23]. Indicators are useful for setting performance targets for assessing progress towards targets and comparing the performance of different work units, organizations, ministries, or institutions (Keith, 2008). The weakness of the current regional government performance measurement system is that performance measurement has not focused on outcomes but is still output-oriented. This is because the regional government has not been able to determine the outcome, benefit, and impact indicators appropriately [24]. The result of the analysis of performance achievements at BAPPEDA of Merangin Regency shows that the achievementof targets cannot be realized $100 \%$ in accordance with the targets that have been set and only $89.83 \%$ have been implemented. This is because there are new programs and activities. Furthermore, during the implementation of these programs and activities, they require some adjustments [15].

\section{Methods}

The type of this study was descriptive research, which is based on the basic question ofhow. Furthermore, the focus of this study was to determine the extent of the success of the regional governments in implementing cascading to achieve the Regional Government Performance Accountability in Kerinci Regency, Jambi Province and Rejang Lebong Regency, Bengkulu Province. The data used in this study were primary data and secondary data. Those data were collected through observation, interviews, documentation, and triangulation. The main data collection tool or instrument was the researchers themselves, in which the researchers were directly involved in this study. Therefore, the researchers gained a deep understanding of what was being investigated.

In this study, informants were selected through purposive sampling and snowball sampling. Based on these techniques, the selected key informants were the Secretary of the Regional Development Planning, Research, and Development Agency (Indonesian: Badan Perencanaan Pembangunan, Penelitian, dan Pengembangan Daerah (PPPPD)), the Secretary of the Inspectorate, the Secretary of the Regional Finance and Revenue Management Agency (Indonesian: Badan Pengelolaan Keuangan dan Pendapatan Daerah (BPKPD)), and the Head of the Organizational Section of Kerinci Regency, Jambi Province and Rejang Lebong Regency, Bengkulu Province. Information from key informants is followed up by determining the next informants. Those informants are the Head of the Sub-Division for Planning Documents, the Head of the Sub-Division for Budget Planning, the Head of the Sub-Division for the Monitoring, Control, and Evaluation of PPPPD, and the Head of the Sub-Division for Planning, Evaluation, and Reporting of BPKPD, from Kerinci Regency, Jambi Province and Rejang Lebong Regency, Bengkulu Province. Besides, the researchers also determined informants from other offices, namely the Head of Sub-Division and Staff for Program Preparation and Reporting. In this study, the procedures are as follows :

a. Conducting a literature study on the applicable rules or policies, starting from regional 
planning to the Government Agency Performance Accountability Report.

b. Requesting Planning Documents and the Government Agency Performance Accountability Report from related parties.

c. Making research instruments.

d. Comparing Planning Documents, the Government Agencies Performance Accountability System Procedures, and the Government Agency Performance Accountability Report with the laws and regulations applied by regional governments.

e. Conducting interviews with informants.

f. Processing the collected data, both primary and secondary data.

g. Analyzing the data.

h. Drawing conclusions

\section{Results and Discussion}

\subsection{An Overview of Kerinci and Rejang Lebong Regencies}

Kerinci and Rejang Lebong Regencies have mountainous areas and possess similar cultures, climates, and people's livelihoods. Kerinci Regency is one of the regencies in Jambi Province, located at coordinates $01^{\circ} 40^{\prime}-02^{\circ} 26^{\prime} \mathrm{S}$ and $101^{\circ} 08^{\prime}-101^{\circ} 50^{\prime} \mathrm{E}$, with the total area of 332,807 ha or $3328.14 \mathrm{~km}^{2}$. This regency has 16 districts and 285 sub-districts. In the north, it is bordered by South Solok Regency, West Sumatra Province. In the south, it is Merangin Regency, Jambi Province and Muko-muko Regency, Bengkulu Province. In the west, it is Pesisir Selatan Regency, West Sumatra Province and Sungai Penuh City, Jambi Province. Furthermore, in the east, it is Merangin Regency and Bungo Regency, Jambi Province.Meanwhile, Rejang Lebong Regency is one of the regencies in Bengkulu Province, which is located at coordinates $102^{\circ} 19^{\prime}-102^{\circ} 57^{\prime} \mathrm{E}$ and $2^{\circ} 22^{\prime} 07^{\prime \prime}-3^{\circ} 31^{\prime} \mathrm{S}$. This regency is sharing a border with South Sumatra Province in the north and east, Kepahiang Regency in the south, Lebong Regency in the north, and North Bengkulu Regency in the west. The total area of thisregency is 151,576 ha, consisting of 15 districts, 127 villages, and 31 urban villages.

In carrying out the government and ensuring that the government can run effectively in accordance with its main tasks and functions, the governments of Kerinci Regency for the 2014 - 2019 period and Rejang Lebong Regency for the 2016 - 2021 period have a government structure consisting of the Regent, Deputy Regent, Secretary, and Departments / Agencies / Offices.

\subsection{Results}

The Implementation of Cascading in Realizing the Achievement of Key Performance Indicators for Regional Heads

From the results of interviews and a review of Planning Documents, the governments of Kerinci and Rejang Lebong Regencies have carried out cascading by identifying what will be achieved based on the vision, mission, goals, and objectives of the governments. The cascading process carried out depends on the ability of OPD to collect, process, and analyze the data needed in order to identify what will be achieved. They have prepared the performance tree when OPD begins to outline the objectives of the KPIs for OPD by considering KPIs for the Regional Governments. The KPIs for OPD are prepared in line with the goals and objectives 
of regional government development. The preparation of these KPIs is inseparable from the Strategic Plan (Indonesian: Rencana Strategis (RENSTRA)) and the Regional Medium-Term Development Plan (Indonesian: Rencana Pembangunan Jangka Menengah Daerah (RPJMD)), which are guided by Indonesia's Minister of Empowerment of State Apparatus and Bureaucratic Reform Regulation No. 12/2015 and Indonesia's Minister of Home Affairs Regulation No. 90/2020. The performance tree is re-analyzed when OPD prepares the Work Plan and Annual Performance Plan with adjustments to the performance indicators that have been targeted annually in the Strategic Plan. The preparation of cascading and the performance tree is carried out by outlining the vision and mission of the regional head and reducing the strategic targets at the regency level. It is then continued to the level of OPD hierarchically, starting from echelon II, echelon III, and echelon IV. All of these have been carried out by the governments of Kerinci and Rejang Lebong Regencies to equate the KPIs for the regional government with the KPIs for each OPD. Furthermore, this process is carried out very carefully because not all performance indicators, especially at the regional government and echelon II level, can be cascaded down to the lower level.

The differences in the formulation and targets of KPIs in the Work Plan of SKPD and RKA SKPD with performance determination in Kerinci and Rejang Lebong Regencies cause a lack of direct linkage between funding and performance. So far, there is no mechanism for revising the KPIs in the Work Plan of SKPD and RKA SKPD after the fiscal year is running. However, the provisions regarding the revision of the KPIs have not yet been regulated in the relevant regulations. There are no provisions that explicitly regulate whether it is permissible to revise the KPIs in the Work Plan of SKPD and RKA SKPD in the running fiscal year to adjust to the KPIs in performance determination. To further demonstrate the direct link between funding and the performance to be achieved, it is deemed necessary to have a mechanism for revising the KPIs in the Work Plan of SKPD and RKA SKPD.

The performance management document in the form of performance determination is prepared no later than January of the running fiscal year. Meanwhile, planning and budgeting documents (Work Plan of SKPD and RKA SKPD) are prepared before the fiscal year is running. The difference in the time limit for this preparation causes the determination of the KPIs in the Work Plan SKPD and RKA SKPD to refer to the documents of the Determination Contract of the previous year. In fact, the formulation of the KPI target so far has changed every year, in terms of additions, subtractions, and others. These changes, in addition to adjusting to actual conditions, are also due to the fact that the work unit has not been able to formulate KPIs that can truly become a benchmark for achieving organizational goals and objectives. Therefore, the timing of the preparation of documents in the governments of Kerinci and Rejang Lebong Regencies needs to be adjusted. In this case, the preparation of the performance determination must be carried out before the fiscal year is running. With this adjustment, it is expected that the determination of the KPIs in the Work Plan of SKPD and RKA SKPD will not experience difficulties. In addition, there will be no more differences in KPIs.

Key Performance Indicators (KPIs) are indicators used to measure the strategic goals and objectives of the government, more commonly known as KPIs for Regent or KPIs for Regional Heads. KPIs may describe the performance target of the regional government in line with the core business of the regional governments. In this study, those regional governments are the governments of Kerinci and Rejang Lebong Regencies. KPIs are contained in the strategic goals and objectives of the organization so that KPIs are a measure of the success of an organization's strategic goals and objectives. In other words, KPIs can be used as a measure of the success of the regional government. KPIs at each organizational unit level include output 
and outcome indicators, as shown in the following order.

1. At the regional head level, it at least must use outcome indicators based on itsauthorities, duties, and functions.

2. At the Echelon I work units, it must use outcome indicators and/or output indicatorsthat are one level higher than that in the lower work units.

3. At the Echelon II work units, it must use outcome indicators

The process of cascading carried out in Kerinci and Rejang Lebong Regencies always determines the programs and activities that will be carried out in a certain year. Therefore, the organizational unit must plan programs and activities according to the predetermined success measures every year. Furthermore, the planned programs and activities must be submitted for budget proposals in the documents of RKA for organizational units. After the implementation of programs and activities, a measurement must be conducted based on the established KPIs. The results of this measurement are then stated in the performance report of the relevant agency and become the basis for implementing performance evaluations to realize continuous performance improvements.

\section{Conclusions}

The cascading implemented by the governments of Kerinci and Rejang Lebong Regencies in realizing the KPIs for Regional Heads has started to run well from year to year. However, it has not been optimal in its implementation, seen from the results of the assessment in the Government Agency Performance Accountability Report (Indonesian: Laporan Akuntabilitas Kinerja Kinerja Instansi Pemerintah (LAKIP)), in which the governments fromboth regencies still get the predicate B. It means that the governments of Kerinci and Rejang Lebong Regencies have been not maximum in the implementation of cascading because it is anew thing in regional government. In addition, regulations and competitive human resources are the main obstacles for the governments of Kerinci and Rejang Lebong Regencies.

The governments of Kerinci and Rejang Lebong Regencies are guided by Indonesia's Minister of Empowerment of State Apparatus and Bureaucratic Reform Regulation No. 12/2015 concerning the Guidelines for Evaluation of the Implementation of the Government Agency Performance Accountability System (Indonesian: Sistem Akuntabilitas Kinerja Instansi Pemerintah (SAKIP)) and Indonesia's Presidential Regulation No. 29/2014 concerning SAKIP. The assessment of SAKIP is very dependent on the quality of cascading carried out by each SKPD in Kerinci Regency, Jambi province and Rejang Lebong Regency, Bengkulu province. The more the SKPD that applies good cascading is, the better the score of SAKIP obtained by the regional government will be better. It is because one of the assessment indicators of SAKIP is the quality of cascading.

\section{Implications}

For regional governments, by carrying out good and correct cascading in the process of elaborating and aligning the Strategic Goals, Key Performance Indicators (KPIs), and the targets of KPIs, activities in each SKPD can be seen clearly in supporting the vision and mission of the regional head, starting from KPIs for Regents to KPI for the Head of SKPD, KPIs for Echelon III, and KPIs for Echelon IV. It is to establish the Government Agency Performance Accountability System in realizing Bureaucratic Reform, namely (a) clean, accountable, and high-performing government (b) effective and efficient government, and (c) 
good and quality public services.

The results of this study are expected to have theoretical implications in strengthening existing theories and to be used as a formulation in discussing the results of this study. The results of this study support and strengthen the goal-setting theory, in which clear goal setting can increase the performance accountability of regional government agencies. The regional governments have carried out the process of formulating planning and budget documents whichinclude the objectives and programs of the regional government, which are then transform intoRPJMD. Setting goals in planning documents through good cascading can result in clarity of goals and high commitment for Echelon II, Echelon III, and Echelon IV officials in each SKPDof regional governments.

\section{Limitations}

The limitations of this study are that this study was conducted in several Regional Apparatus Organizations (Indonesian: Organisasi Perangkat Daerah (OPD)) in Kerinci and Rejang Lebong Regencies, not all officials in those Regional Apparatus Organizations were appointed as informants, and the informants were only several echelon officials who were directly related to planning and reporting processes.

\section{Recommendations}

Based on the various limitations in this study concerning the implementation of cascading in governments of Kerinci and Rejang Lebong Regencies, the recommendations to further research with the theme of cascading are as follows.

1. Make comparisons between the central government, provincial governments, and regency/city governments. This comparison will be able to provide information to the reader regarding the process of elaboration and synchronization of each planning document that has been predetermined.

2. Conduct studies by comparing regional governments based on the category in the assessment of the Government Agency Performance Accountability Report (Indonesian: Laporan Akuntabilitas Kinerja Instansi Pemerintah (LAKIP)), such as regional governments that get the predicates A, BB, and CC. Considering the differences in these categories can be used as a reference and comparison for governments that have not received a good predicate.

\section{References}

[1] J. Febriantoko, "Proses Penyusunan Dokumen Perencanaan Dan Laporan Pertanggungjawaban Pemerintah Daerah Di Indonesia: Pendekatan Kualitatif," Media Trend, vol. 12, no. 2, pp. 143-155, 2017, doi: 10.21107/mediatrend.v12i2.3067.

[2] A. Halik, "Kajian Pengembangan Kebijakan Pelayanan Terpadu Satu Pintu (PTSP) melalui Perspektif Indikator Kinerja Utama (IKU)," J. Bina Praja J. Home Aff. Gov., vol. 6, no. 1, pp. 1-18, 2014, doi: 10.21787/jbp.06.2014.41-50.

[3] L. Kloot, "Performance measurement and accountability in Victorian local government," Int. J. Public Sect. Manag., vol. 12, no. 7, pp. 565-584, 2009, doi: 10.1108/09513559910308039.

[4] M. Kristiyanti, "Peran Indikator Kinerja Dalam Mengukur Kinerja Manajemen," Maj. 
Ilm. Inform., vol. 3, no. 3, 2012.

[5] F. H. Palenga, "Evaluasi Penerapan Sistem Akuntabilitas Kinerja Instansi Pemerintah (Studi Pada Biro Organisasi Sekretariat Daerah Provinsi Sulawesi Tengah)," Katalogis, vol. 5, no. 1, 2017.

[6] K. Mackay, "Establish a monitoring and evaluation system, for realizing better government," Int. J. Public Sect. Manag., 2012.

[7] F. I. Mariandini, G. Irianto, and Nurkholis, "Institusionalisasi Sistem Akuntabilitas Kinerja Instansi Pemerintah Di Pemerintah Kota Malang," J. Econ., vol. 14, no. 1, 2018.

[8] I. Balabonienè and G. Večerskienè, "The aspects of performance measurement in public sector organization,” Procedia-social Behav. Sci., vol. 213, pp. 314-320, 2015, doi: $10.1016 /$ j.sbspro.2015.11.544.

[9] R. H. Chenhall and P. Brownell, "The effect of participative budgeting on job satisfaction and performance: Role ambiguity as an intervening variable," Accounting, Organ. Soc., vol. 13, no. 3, pp. 225-233, 2008, doi: 10.1016/0361-3682(88)90001-3.

[10] S. P. Robbins and M. Coulter, Management, 11th ed. New Jersey: Prentice Hall, 2012.

[11] S. P. Robbins, Organizational Behaviour, 10th ed. Jakarta: Salemba Empat, 2008.

[12] F. C. Lunenburg, "Goal-Setting Theory of Motivation," Int. J. Manag. Business, Adm., vol. 15, no. 1, pp. 1-6, 2011, [Online]. Available: http://www.nationalforum.com/Electronic Journal Volumes/Lunenburg, Fred C. GoalSetting Theoryof Motivation IJMBA V15 N1 2011.pdf.

[13] M. C. Jensen and W. H. Meckling, "Theory of the Firm: Managerial Behavior, Agency Costs and Ownership Structure," J. financ. econ., no. 3, pp. 82-137, 1976.

[14] E. L. Raharja, L. M. Baga, and A. F. Falatehan, "Strategi Peningkatan Akuntabilitas Kinerja Instansi Pemerintah Kota Bogor,” J. Manaj. Pembang. Drh., vol. 10, no. 2, 2018.

[15] A. D. N. Osrinda, "Implementasi Akuntabilitas Kinerja Dalam Reformasi Birokrasi Di Kementerian Keuangan Republik Indonesia,” J. Perspect. Financ. Reg. Dev., vol. 3, no. $1,2016$.

[16] N. P. S. P. Dewi, E. A. Sisdyani, and I. . G. A. M. A. D. Putri, "Implementasi Balanced Scorecard Dalam Penyusunan Rencana Strategis Di Rumah Sakit Umum Daerah Wangaya Kota Denpasar," E-Jurnal Akunt. Univ. Udayana ISSN, vol. 18, no. 2, pp. 965-995, 2017.

[17] Syulfa, "Evaluasi Sistem Akuntabilitas Kinerja Instansi Pemerintah: Studi pada Kabupaten Bangka Tengah,” Tesis Gelar Magister. Universitas Gajah Mada, 2016.

[18] D. Li and A. Madden, "Cascade embedding model for knowledge graph inference and retrieval," Inf. Process. Manag., vol. 56, no. 6, p. 102093, 2019, doi: 10.1016/j.ipm.2019.102093.

[19] G. Pescaroli, "Perceptions of cascading risk and interconnected failures in emergency planning: Implications for operational resilience and policy making," Int. J. disaster risk Reduct., vol. 30, pp. 269-280, 2018.

[20] L. Kloot and J. Martin, "Strategic performance management: A balanced approach to performance management issues in local government," Manag. Account. Res., vol. 11, no. 2, pp. 231-251, 2000, doi: 10.1006/mare.2000.0130.

[21] K. F. Dewi, A. Putra, and I. B. P. Astika, "Pengaruh budaya organisasi, pengendalian internal dan kejelasan sasaran anggaran pada akuntabilitas kinerja SKPD Kabupaten Gianyar dengan komitmen organisasi sebagai variabel moderasi,” J. Bul. Stud. Ekon., vol. 22, no. 1, pp. 21-33, 2017. 
[22] Fachruzzaman, "Pengaruh Tipe Sistem Pengukuran Kinerja dan Kepedulian Manajemen Terhadap Kinerja Program dan Kinerja Keuangan Pada Dinas Pendidikan Kabupaten dan Kota Di Provinsi Bengkulu,” 2009, doi: 10.35448/jte.v14i2.6478.

[23] H. Yusrianti and R. H. Safitri, "Implementasi Sistem Akuntabilitas Kinerja Instansi Pemerintah (SAKIP) Pada Satuan Kerja Perangkat Daerah (SKPD) Di Lingkungan Pemerintah Kota Palembang," J. Manaj. dan bisnis Sriwij., vol. 13, no. 4, pp. 545-558, 2015.

[24] Y. S. Ulimpa, J. J. Sondakh, and T. Runtu, "Analisis Pengukuran Kinerja Pemerintah Daerah Dalam Era Otonomi Daerah Di Kabupaten Sorong Provinsi Papua Barat," Going Concern J. Ris. Akunt., vol. 13, no. 04, 2018. 